Arq. Bras. Med. Vet. Zootec., v.64, n.2, p.359-362, 2012

\title{
Fibrodysplasia ossificans progressiva-like in a cat
}

\author{
[Fibrodisplasia ossificante em gato] \\ L.Z. Crivelenti ${ }^{1}$, S. Borin ${ }^{1}$, A.M. Brum ${ }^{2}$, D.K. Honsho ${ }^{2}$ \\ ${ }^{1}$ Universidade Estadual Paulista "Júlio de Mesquita Filho" - UNESP-Jaboticabal, SP \\ ${ }^{2}$ Universidade de Franca - UNIFRAN - Franca, SP
}

\begin{abstract}
Fibrodysplasia ossificans progressiva-like (FOP-like) was diagnosed in a young Brazilian cat presenting progressive lameness, pain upon manipulation and inability to extend the hind limbs. Due to poor response to medication described in the literature, only orchiectomy and confinement of the patient were recommended. The patient described here has been observed for four years and the animal is currently in fair condition despite the movement restrictions.
\end{abstract}

Keywords: feline, myositis ossificans, heterotopic ossification

\section{RESUMO}

Fibrodisplasia ossificante progressiva (FOP)-like foi diagnosticada em um felino brasileiro jovem com claudicação progressiva, atrofia, incapacidade de extensão e dor a manipulação dos membros pélvicos. Em razão de insuficiência nas respostas aos medicamentos observados na literatura foi preconizado apenas orquiectomia e confinamento do paciente. Apesar de a maioria dos relatos de FOP-like indicar eutanásia, o presente caso está sendo acompanhado há quatro anos, desde o diagnóstico, e apesar de o paciente manter-se com restrições de deambulação, encontra em condições satisfatórias.

Palavras-chave: felino, miosite ossificante, ossificação heterotópica

\section{INTRODUCTION}

Fibrodysplasia ossificans progressiva (FOP), also known as myositis ossificans progressiva or Münchmeyer's disease (Campos et al., 2005), is a rare disease in humans (Palhares and Leme, 2001) and animals (Guilliard, 2001; Kaplan et al., 2005; Asano et al., 2006).

In humans, it exhibits autosomal dominant inheritance with variable expressivity, despite the fact that many cases are sporadic (Palhares and Leme, 2001). It is characterized by ectopic bone formation involving fasciae, aponeuroses, ligaments, tendons, interstitial connective tissue of skeletal muscles (Palhares and Leme, 2001) and joint capsules (Araujo et al., 2005), which may or may not be induced by trauma and results in permanent muscular and articular immobility (Campos et al., 2005). Furthermore, the pathogenesis of FOP in humans is associated with mutations in chromosome 4q2-31 which seems to modify the expressivity of bone morphogenetic protein 4 (BMP-4), a factor which is probably involved in maintenance and expansion of ectopic ossification (Campos et al., 2005; Kan et al., 2004).

Information about fibrodysplasia ossificans progressiva-like (FOP-like) in veterinary medicine is limited due to the small number of reports regarding the natural occurrence of ectopic ossification in animals (Guilliard, 2001; Kaplan et al., 2005; Asano et al., 2006). Based on the literature consulted, it was assumed that only eight cases of FOP-like conditions have been described in cats all over the world (Asano et al., 2006; Yabuzoe et al., 2009), and this work constitutes the ninth description of this disease in this species.

Recebido em 6 de novembro de 2011

Aceito em 12 de janeiro de 2012

E-mail: Crivelenti_lz@yahoo.com.br 


\section{Crivelenti et al.}

\section{CASE REPORT}

A two-and-a-half-year-old male mongrel cat weighing $3.9 \mathrm{~kg}$ was referred to the Teaching Veterinary Hospital in Franca, SP, Brazil, with a history of progressive lameness, pain upon manipulation and an ongoing inability to extend the hind limbs for more than three months.

Radiographic studies revealed the presence of calcification in the hind limb muscle. The laboratory work showed increased serum creatine kinase activity (244U/L), without other major alterations.

Macroscopically, the ectopic tissue was a whitish, strongly adherent, weakly vascularized, firm nodule located between the vastus lateralis and biceps femoris muscles and the fascia lata. After resection, the microscopic examination showed a mature bone tissue with preserved trabeculae and an active and hypercellular bone marrow (Figure 1).
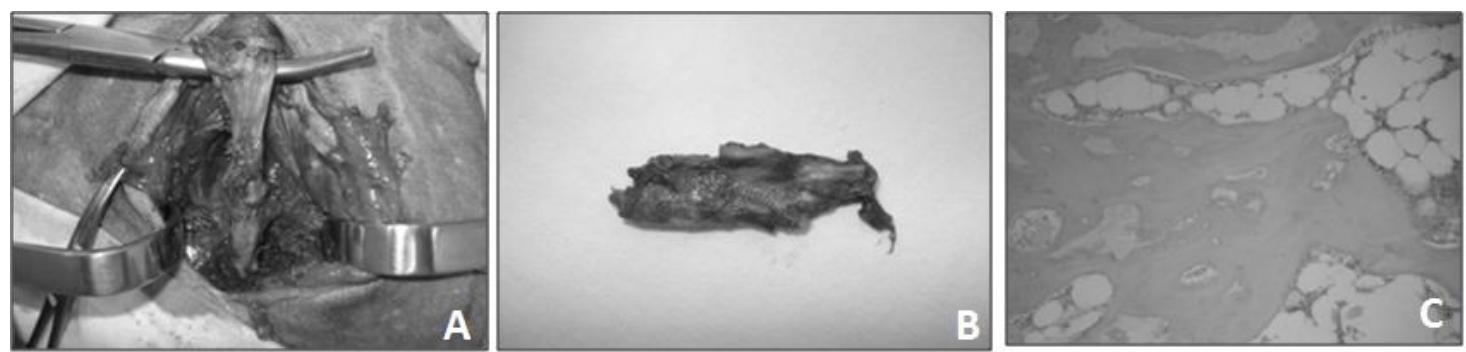

Figure 1. Cat. Photographs of the ectopic bone tissue. A) First ossification at surgical site. B) Macroscopic appearance of dissected tissue specimen. C) Histological bone marrow of the tissue specimen.

Three months after surgery, new bony structures were observed. One was present on the same location as the first and the other was located between the gluteus medius and sartorius muscles, on the upper quadrant of the other hind limb (Figure 2A and 2B). An additional surgical procedure was performed for resection of both neoformations and orchiectomy.
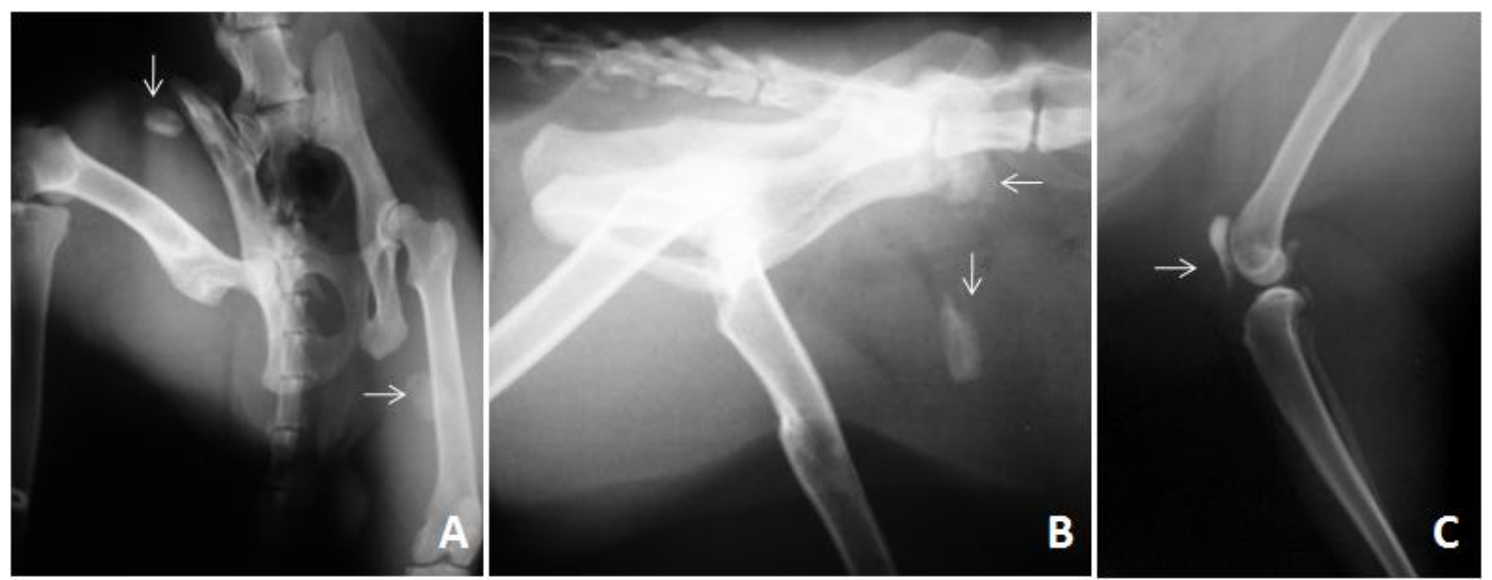

Figure 2. Cat. Two new nodules in A and B, before the second surgery. In C, radiograph taken two years after the last surgery, showing ossification of the patellar tendon and joint capsule.

The diagnosis of FOP-like was established after repetition of the histopathological findings. After four years, the animal is clinically stable. It exhibits muscle atrophy, moderate lameness and inability to extend both hind limbs. Radiographic evaluation revealed new foci of ectopic ossification in areas which include the patella (Figure 2C), even though these exhibited low progression. 


\section{RESULTS AND DISCUSSION}

An early and correct diagnosis of FOP is essential for the establishment of appropriate management of the patient. Even though the therapeutic possibilities are limited, attention to the characteristic clinical signs of the disease could avoid unnecessary biopsies and surgeries (Palhares and Leme, 2001). Unfortunately, in light of the few cases described in veterinary medicine, histopathology was crucial to differentiate a FOP-like condition from neoplasia.

As in the majority of cases reported in cats, the initial ossification was observed on the thigh and hind limb (Yabuzoe et al., 2009). No irregularities in the phalanges or any congenital abnormalities were observed, as described for humans (Cohen et al., 1993; Campos et al., 2005).

Laboratory exams did not reveal leukocytosis or increased serum alkaline phosphatase activity, as seen in a feline case reported by Yabuzoe et al. (2009), nor alterations in serum concentration of calcium and phosphorus which could indicate metabolic disorders and metastatic mineralization (Guilliard, 2001). The only relevant finding was an increase in serum creatine kinase activity, which corroborates other reports (Asano et al., 2006).

Differently from the cases of canines with FOPlike conditions (Guilliard, 2001), the disease has not been observed in older cats: the average age in the reports was 2.6 years (ranging from 10 months to 6 years) (Warren and Carpter, 1984; Asano et al., 2006; Yabuzoe et al., 2009).

The animal described here exhibited progressive ossification of connective tissue, which caused increasing limitation of osteoarticular mobility and pain upon manipulation, similarly to the majority of cases (Asano et al., 2006). Despite the bad prognosis, in which death can occur due to restriction of respiratory movements and to bronchi ossification (Araujo et al., 2005; Yabuzoe et al., 2009), as well as euthanasia, described in most described reports, the owner opted for keeping the patient confined and performing periodic radiographic evaluations. Even though this is an isolated case, such evaluations allowed us to hypothesize that FOP's pulmonary complications may not be as frequent in cats as they are in humans.

Histology of early lesions usually show infiltrates with lymphocytes, macrophages and fibroblasts, which later progress to areas of connective tissue with central ossification with osteoblasts, osteocytes and osteoclasts and active bone marrow (Asano et al., 2006; Araujo et al., 2005). In all biopsies, it was possible to observe endochondral ossification which exhibited normal osteogenesis, active bone marrow tissue and fibrous proliferation of the fascia, but with no degeneration of muscle cells and high vascular fibroproliferation as described for humans (Kan et al., 2004).

It should be emphasized that physical activity and parenteral administration of drugs should be limited to avoid trauma and emergence of new ossification sites (Palhares and Leme, 2001). To this end, the animal underwent orchiectomy and was confined inside the owner's residence.

In general, the results of treatments in both humans and animals are frustrating. Etretinate disodium, a synthetic Vitamin A compound, has been used at $1 \mathrm{mg} / \mathrm{kg}$ (PO, SID) to treat FOP-like conditions but yielded no beneficial results. Other drugs such as Vitamin E, selenium and prednisone have also been evaluated but none of the treatments is considered effective until now (Asano et al., 2006). One of the treatments with fewer side effects in humans is the use of ascorbic acid, which seems to stabilize the disease (Palhares e Leme, 2001). This approach was suggested as part of the treatment for the cat described here, but the owner disagreed with it and, therefore, the evaluation of the effects of this drug in this case could not be assessed.

\section{REFERENCES}

ARAÚJO JÚNIOR, C.R.; CARVALHO, T.N.; COSTA, M.A.B. et al. Fibrodysplasia ossificans progressiva: a case report and radiographic findings. Radiol. Bras., v.8, p.69-73, 2005.

ASANO, K.; SAKATA, A.; SHIBUYA, H. et al. Fibrodysplasia ossificans progressiva-like condition in cat. J. Vet. Med. Sci., v.68, p.10031006, 2006. 
CAMPOS, D.M.; RENCK, D.V.; BEBBER, F.E. et al. Fibrodysplasia ossificans progressiva: a case report. Radiol. Bras., v.38, p.393-395, 2005.

COHEN, R.B.; HAHN, G.V.; TABAS, J.A. The natural history of heterotopic ossification in patients who have fibrodysplasia ossificans progressiva. A study of forty-four patients. $J$. Bone Jt. Surg., v.75, p.215-219, 1993.

GUILLIARD, M.J. Fibrodysplasia ossificans in a German shepherd dog. J. Small Anim. Pract., v.42, p.550-553, 2001.

KAPLAN, F.S.; SHORE, E.M.; PIGNOLO, R.J. et al. Animal models of fibrodysplasia ossificans progressive. Clin. Rev. Bone Min. Metab., v.3, p.229-234, 2005.
KAN, L.; HU, M.; GOMES, W.A. et al. Transgenic mice overexpressing bmp4 develop a fibrodysplasia ossificans progressiva (FOP)-Like phenotype. Am. J. Pathol., v.165, p.1107-1115, 2004.

PALHARES, D.B.; LEME, L.M. A perspective on the control of myositis ossificans progressiva. J. Pediatr., v.77, p.431-434, 2001.

YABUZOE, A.; YOKOI, S.; SEKIGUCHI, M. et al. Fibrodysplasia ossificans progressiva in a Maine Coon cat with prominent ossification in dorsal muscle J. Vet. Med. Sci., v.71, p.16491652, 2009.

WARREN, H.B.; CARPENTER, J.L. Fibrodysplasia ossificans in three cats. Vet. Pathol., v.21, p.495-499, 1984. 